\section{Relative Changes in Polyamines during Citrus Flower Development}

\author{
Mosbah M. Kushad ${ }^{1}$ and Andrea R. Orvos \\ Department of Horticulture, Virginia Polytechnic and State University, \\ Blacksburg, VA 24061-0327
}

George Yelenosky ${ }^{2}$

Agricultural Research Service, U.S. Department of Agriculture, Orlando, FL 32803

Additional index words. cell division, Citrus sinensis, conjugated polyamines

Abstract. Several stages of citrus (Citrus sinensis L. Osbeck. cv. Valencia) flowers, from very small bud (stage 1) to anthesis (stage 6), were evaluated for free and conjugated polyamines. The concentration of putrescine and spermidine synthesis increased markedly during the early stages, and then declined as the flower buds grew. At anthesis, putrescine and spermidine concentrations had increased significantly. Spermine concentration was very low and showed no significant change during the first three floral developmental stages; however, by stages 5 and 6 , spermine concentration showed a slight but significant increase. Eighty percent of the total polyamine content in fully developed flowers is localized in the reproductive organs and only $20 \%$ is localized in the petals and the calyx. This study relates changes in conjugated and free polyamines to citrus flower growth.

Polyamines have been shown to increase during cell proliferation of eukaryotes and prokaryotes (Slocum et al., 1984; Smith, 1985). Montague et al. (1978, 1979) re-

Received for publication 28 Sept. 1989. Mention of a trademark, warranty, proprietary product, or vendor does not constitute a guarantee by the USDA and does not imply its approval to the exclusion of other products or vendors that may also be suitable. The cost of publishing this paper was defrayed in part by the payment of page charges. Under postalregulations, this paper therefore must be hereby marked advertisement solely to indicate this fact.

'Assistant Professor.

${ }^{2}$ Professor. ported a 2-fold increase in putrescine (PUT) and spermidine (SPD) concentrations, together with increased ornithine decarbovlase activity, in embryogenic compared to nonembryogenic carrot cell cultures. In addition, polyamines have been associated with DNA and protein biosynthesis (Kushad et al., 1988; Slocum and Galston, 1985). Slocum and Galston (1985) concluded that polyamines may play a role in regulating the post-fertilization growth and development of tobacco ovaries. Recent studies have established a link between PUT and SPD concentrations and reproductive differentiation. Relatively low levels of polyamines have been reported in nonflowering compared to flow- ering lines of tobacco (Dumas et al., 1981). In addition, Malmberg et al. (1985) described several polyamine-deficient tobacco mutants that were either unable to flower or produced flowers with abnormal morphologies. Male- sterile lines of Zea mays were found to have no hydroxycinnamic acid amide-conjugates of polyamines, while significant amounts of these conjugates were detected in the normal fertile plants (MartinTanguy et al., 1979). Kaur-Sawhney et al. (1988) and Tiburcio et al. (1988) reported that the SPD level was significantly higher in floral buds than in vegetative buds of tobacco. Kaur-Sawhney et al. (1988) also observed that inhibition of SPD synthesis, in the same cultures, reduced flower initation and promoted vegetative bud formation.

Previous studies have evaluated polyamine levels in fully developed flowers and/or in developing fruit (Biasi et al., 1988; Kushad et al., 1988; Palavan and Galston, 1982). Since changes in polyamine levels in developing flower buds have not been determined, the objective of this study was to evaluate free, and conjugated polyamines relative to citrus flower growth.

Citrus flowers were collected from E-yearold 'Valencia' trees grafted on 'Sour Orange' rootstock grown on sandy loam soil in a commercial orchard located in Leesburg, Fla. The various growth stages of flower buds (from small buds to anthesis) were collected from five trees at the same time. Flower buds and flower organs were immediately frozen in liquid $\mathrm{N}$, lyophilized, and stored at $-80 \mathrm{C}$ for further analysis.

Three replicates from each growth stage (20 flower buds per replicate) were homogenized in $5 \%(\mathrm{v} / \mathrm{v})$ perchloric acid at 0.1 $\mathrm{g} \cdot \mathrm{ml}^{-1}$, using a Polytron homogenizer (Brinkman Institute, Westbury, N.J.). The homogenate was centrifuged for $30 \mathrm{~min}$ at $27,000 \times \mathrm{g}$ and the supernatant was assayed for unconjugated (free) polyamines accord- 


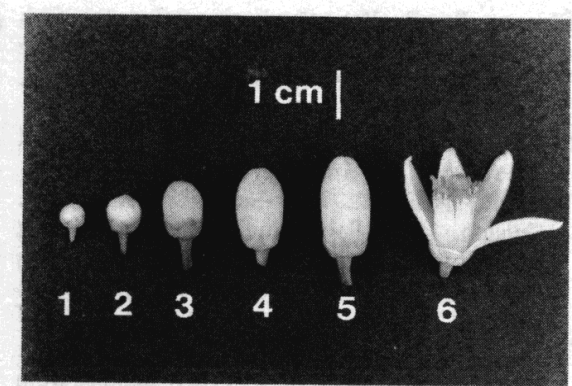

Fig. 1. Stages of 'Valencia' flower buds tested.

ing to Flores and Galston (1982). Two milliliters of $2 \mathrm{~N} \mathrm{NaOH}$ and $5 \mu \mathrm{l}$ of benzoyl chloride were added to a $500-\mu 1$ aliquot of the tissue extract. The mixture was vortexed for $10 \mathrm{sec}$ and incubated at $30 \mathrm{C}$ for $20 \mathrm{~min}$. The benzoylation reaction was terminated by adding $2 \mathrm{ml}$ saturated $\mathrm{NaCl}$, and the benzoylated polyamines were extracted with 4 $\mathrm{ml}$ chilled diethyl ether. The ether was evaporated and the residues were resuspended in $200 \mu \mathrm{l}$ methanol. A $20-\mu 1$ fraction of the benzoylated, polyamines/methanol mixture was injected into a Hitachi HPLC system equipped with UV detector and a C-18 reverse phase column $(30 \mathrm{~cm} \times 4 \mathrm{~mm})$. The assay condition consisted of an isocratic elution of $60 \%$ methanol at room temperature. Conjugated polyamines in the pellet and in the supernatant were released by digesting the samples in a final concentration of $9 \mathrm{~N}$ $\mathrm{HCl}$ in flame-sealed glass ampules before further analysis. In addition, total and conjugated polyamines in the ovary, style, stamens, and combination of petals and calyx were analyzed separately in fully developed flower buds.

Stages of 'Valencia' flower buds are illustrated in Fig. 1. Selection of these stages was based mainly on flower size as described by Frost and Soost (1968). Spermidine and PUT concentrations at flower stage 2 had increased by $50 \%$ and $400 \%$, respectively, relative to stage 1 and then declined toward stages 3 and 4 (Fig. 2). At stage 4, PUT and SPD concentrations were similar to those at stage 1. Putrescine and SPD concentrations increased significantly by stage 6 (Fig. 2) and peaked in the-fruit at $\approx 4$ weeks after anthesis (data not shown). The high level of PUT and SPD concentrations in stage 6 may have resulted from their enhanced synthesis in the ovary (Table 1). Spermine (SPM) concentration was low during the first three stages of flower growth, then steadily increased toward stages 4, 5, and 6 (Fig. 2). The high concentration of SPM at stages 4,5 , and 6 was mainly due to the conjugated form.

A higher ratio of PUT to SPD was observed in stages 2 and 6 than in any other stage of 'Valencia' flower development (Fig. 2). This high ratio was maintained even when PUT and SPD concentrations were expressed per bud (data not shown). Nathan et al. (1984) reported a maximum ratio of 30 for PUT and SPD in the rind of young 'Murcott' mandarin fruit. Bachrach (1973) proposed that a high PUT to SPD ratio indicates that the cells are actively dividing, while a decline in this ratio

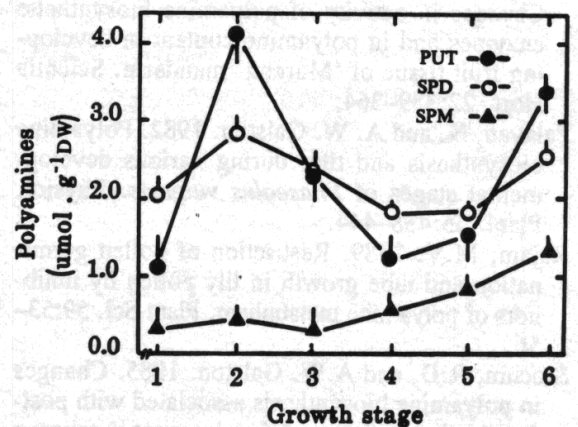

Fig. 2. Polyamine (free and conjugated) levels at the various stages of 'Valencia' flower bud growth shown in Fig. 1.

and in the total PUT and SPD concentrations indicates that tissue growth is primarily by cell enlargement. Frost and Soost (1968) examined stages of reproduction in lemon flowers. They reported active meiotic divisions in the anthers of flower buds equivalent to stage 2. Their report and the high ratio of PUT to SPD in stages 2 and 6 we observed suggest a discrete period of active cell division in these two stages. While not specifically examined in stage 2 , most of the high level of PUT and SPD at stage 6 was in the ovary;

About $75 \%$ of total polyamines were in the conjugated form and only $25 \%$ in the freeform; however, these percentages did not change as the flower increased in size. A high ratio of conjugated to free polyamines has been reported in mature tobacco (Cabanne et al., 1981) and apple flowers (Biasi et al., 1988). Cafeoyl-PUT was shown to accumulate during the later stages of tobacco flower development (Wyss-Benz et al., 1988). Kaur-Sawhney et al. (1988) proposed a positive correlation between high SPD and tobacco flower initiation.

Analysis of total polyamines in stage 6 flower buds showed that $42 \%$ were present in the ovary, $23 \%$ in the style, $15 \%$ in the stamens, and $20 \%$ in the petals and calyx (Table 1). More than $75 \%$ of the total polyamines in the ovary, style, and stamen were in the conjugated form, while only $40 \%$ of the total polyamines in the petals and calyx were in the conjugated form (Table 1). The significance of the high ratio of conjugated to free polyamines in reproductive development is not clear. Conjugated polyamines in the ovary and pistils were reported to contain basic amide conjugates such as caffeoyl-SPD and coumoyl-SPD, while conjugated polyamines in the stamens were reported to be neutral (Cabanne et al., 1981). Therefore, Martin-Tanguy (1985) suggested that the female and the male parts of a flower can be distinguished by the nature of their amide polyamine conjugates. Moreover, transglutaminase (EC 2.3.2.13), which binds polyamines to proteins, was reported to exist in plant tissue (Icekson and Apelbaum, 1987). These conjugates of polyamine-protein were suggested to be responsible for flower initiation in thin-layer tobacco cultures (Apelbaum et al., 1988). Further evidence stressing
Table 1. Distribution of total (free + conjugated) and conjugated polyamines in fully developed citrus flower organs ${ }^{z}$.

\begin{tabular}{lcr}
\hline \hline Flower organ & \multicolumn{1}{c}{$\begin{array}{c}\text { Total } \\
\text { (nmol/organ) }\end{array}$} & $\begin{array}{c}\text { Conjugated } \\
\text { (nmol/organ) }\end{array}$ \\
\hline Ovary & $643 \pm 80$ & $542 \pm 54$ \\
Style & $342 \pm 37$ & $256 \pm 27$ \\
Stamens & $225 \pm 53$ & $175 \pm 18$ \\
Petals and calyx & $309 \pm 61$ & $124 \pm 13$ \\
Flower & 1519 & 1098 \\
\hline
\end{tabular}

${ }^{2}$ Values are the means of three replicates $\pm S E$.

the role of polyamines in flower development was obtained when Rajam (1989) reported that inhibition of polyamine synthesis in lily flowers with difluormethylomithine and difluoromethylarginine suppressed pollen germination and pollen tube growth.

Our data indicate that the bulk of conjugated polyamines is present in the reproductive organs and that changes in total and conjugated polyamines are associated with citrus flower development.

\section{Literature Cited}

Apelbaum, A., Z.N. Canellakis, P.B. Applewhite, R. Kaur-Sawhney, and A.W. Galston, 1988. Binding of spermidine to a unique protein in thin-layer tobacco tissue culture. Plant Physiol. 88:996-998.

Bachrach, U. 1973. Function of naturally occurring polyamines. Academic, New York.

Biasi, R., N. Bagni, and G. Costa. 1988. Endogenous polyamines in apple and their relationship to fruit set and fruit growth. Physiol. Plant.. 73:201-205.

Cabanne, F., M.A. Dalebroux, J. Martin-Tanguy, and C. Martin. 1981. Hydroxycinnamic acid amides and ripening to flower of Nicotiana tabacum var. xanthi n.c. Physiol. Plant. 53:399404

Dumas, E., E. Perdrizet, and J.C. Vallee. 1981. Evolution quantitative des acides amines et amines libres au tours du developpement de diverses espèces de Nicotiana. Physiol. Veg. 19:155-165.

Flores, H.E. and A.W. Galston. 1982. Analysis of polyamines in higher plants by high performance liquid chromatography. Plant Physiol. 69:701-706

Frost, H.B. and R.A. Soost. 1968. Seed reproduction: development of gametes and embryos, p. 290-324. In: W. Reuther, L.D. Batchelor, and H.J. Webber (eds). The citrus industry. Univ. of California, Riverside

Icekson, I. and A. Apelbaum. 1987. Evidence for transglutaminase activity in plant tissue. Plant Physiol. 84:972-974.

Kaur-Sawhney, R., A.F. Tiburcio, and A.W Galston. 1988. Spermidine and flower-bud differentiation in thin-layer explants of tobacco. Planta 173:282-284.

Kushad, M.M., G. Yelenosky, and R.J. Knight. 1988. Interrelationship of polyamine and ethylene biosynthesis during avocado fruit development and ripening. Plant Physiol. 87:463467.

Malmberg, R.L., J. McIndoo, A.C. Hiatt, and B.A. Lowe. 1985. Genetics of polyamine synthesis in tobacco: development switches in the flower. Geld Spring Harbor Symp. vol. 50. Cold Spring Harbor, N.Y. p. 475-482.

Martin-Tanguy, J. 198.5. The occurrence and possible function of acid amides in plants. Plant Growth Reg. 3:381-399. 
in-Tanguy, J., A. Deshayes, E. Perdrizet, and C. Martin. 1979. Hydroxycinnamic acidamides in Zea mays: distribution and changes with cytoplasmic male sterility. FEBS Len. 108:176178.

Montague, M.J., J.W. Koppenbrink, and E.G. Jaworski. 1978. Polyamine metabolism in embryogenic cells of Daucus carota. I. Changes in intracellular content and rates of synthesis. Plant Physiol. 62:430-433.

Montague, M.J., T.A. Armstrong, and E.G. Jaworski. 1979. Polyamine metabolism in embryogenic cells of Daucus carota. II. Changes in arginine decarboxylase activity. Plant Physiol. 63:341-345.

Nathan, R., A. Ahman, and S.P. Monselise. 1984.
Changes in activity of polyamine biosynthetic enzymes and in polyamine content in developing fruit tissue of 'Murcott' mandarin. Scientia Hort. 22:359-364.

Palavan, N. and A. W. Galston. 1982. Polyamine biosynthesis and titer during various developmental stages of Phaseolus vulgaris. Physiol. Plant. 55:438-444.

Rajam, M.V. 1989. Restriction of pollen germination and tube growth in lily pollen by inhibitors of polyamine metabolism. Plant Sci. 59:53 56.

Slocum, R.D. and A.W. Galston. 1985. Changes in polyamine biosynthesis associated with postfertilization growth and development in tobacco ovary tissue. Plant Physiol. 79:336-343.
Slocum, R., R. Kaur-Sawhney, and A.W. Galston. 1984. The physiology and biochemistry of polyamines. Arch. Biochem. Biophys. 235:283-303.

Smith, T.A. 1985. Polyamines Annu. Rev. Plant Physiol. 36:117-143.

Tiburcio, A.F., R. Kaur-Sawhney, and A.W. Galston. 1988. Polyamine biosynthesis during vegetative and floral bud differentiation in thin layer tobacco tissue cultures. Plant Cell Physiol. 29:1241-1249.

Wyss-Benz, M., L. Streit, and E. Elbert. 1988. Hydroxycinnamoyl amides in stem explants from flowering and non-flowering Nicotiana tubacum. Physiol. Plant. 74:294-298. 